Proceedings of the Second Annual Forestry Symposium 1996: Management and Sustainable Utilization of Forest Resources, Sri Lanka, 6-7 December 1996. (Eds. Amarasekera, HS, Ranasinghe, D MS HK and Finlayson, W. Published by Department of Forestry and Environmental Science, University of Sri Jayewardenepura, Sri Lanka (1998)

\title{
FLORISTIC DIVERSITY OF WOODY PERENNIALS IN THE HAKGALA STRICT NATURE RESERVE
}

\author{
Punyalal, M.G. ${ }^{1}$ and Ranasinghe, D.M.S.H.K. ${ }^{2}$ \\ ${ }^{1}$ Forest Department \\ 'University of Sri Jayewardenepura
}

\begin{abstract}
Sampling by the "gradsect" method found that there were 88 woody plant species belonging to 65 genera and 36 families. The trees were of six families: Lauraceae, Theaceae, Symplocaceae, Myrtaceae, Elaeocarpaceae and Rubiaceae. There was no evidence of single species dominance in trees. No major tree communities were observed at the lower elevations, but near the peak there is a community at canopy level of Syzygium umbrosum, Eugenia mabaeoides, and Callophyllum walkeri. There are four dominant species of saplings: Psychotria zeylanica, P. nigra, Maesa perrottetiana, and Lasianthes oliganthes, of which P. zevlanica appears sometimes to be a dominant single species. The dominant families among the saplings are the Rubiaceae and Myrsinaceae, while the seedlings are dominated by Rubiaceae. Biological diversity is high, and endemism was put at $+4 \%$ of the total species enumerated. It is an ecologically critical area, which includes 2 endangered species, 2 vulnerable, 7 rare, and + intermediate. This nature reserve, therefore, has a high conservation value. Its small size and isolation may jeopardize its longterm viability if measures are not taken for its complete protection.
\end{abstract}

\section{Introduction}

\section{Sri Lanka's biodiversity}

Sri Lanka is one of the smallest but biologically most diverse countries in Asia. Consequently. it is recognized as a biodiversity hotspot of global importance. Its extremely high biological diversity, higher than in most other tropical Asian countries when measured per unit area, is due to its varied topography and varied tropical climate. More than 3350 species of flowering plants and 300 species of pteridophytes have been described. As many as $23 \%$ of the species of flowering plants are endemic. Only about $6 \%$ of the endemics are found in the broad dry-zone plains of the north and east, where the flora distribution will have been influenced by the proximity of India. The other $94 \%$ are found in the wet evergreen and wet montane forests of the southwest and south-central part of the island, of which the nearest climatic analogues are in distant western Malaysia. Seychelles and Madagascar. 
Other than the flowering plants, the indigenous flora comprises ferns and fern allies. 314 species; mosses, 575; liverworts, 190: algae, 896; and fungi, 1920. Of the 314 species of fern and allied species. 57 are endemic. The total number of lichen species has not been established. but 110 species have been identified in the family Thelotremataceae. of which 39 are said to be endemic (IUCN, 1993).

Much of this diversity is found in the forests. particularly those in the southwest of the island and central highlands, where conditions are wettest and temperatures most varied. These regions lic in what are referred to as the wet zone and the intermediate zone. The wet south west and south-central region, with a land area of about a quarter of the country. which is the last refugium of the vast majority of Sri Lanka's endemic flora. is also the very area that has suffered the most from deforestation. In the low and mid-country wet zone. for cxample, no more than $9 \%$ of the land area is now under natural forest. Despite the heavy deforestation, areas of forest can still be recognized whose floristic composition shows especially great diversity.

One of them is the Sinharaja forest. the only sizable primeval lowland rain forest now remaining in the country. A phytosociological study of Sinharaja carried ont by Gunatilleke \& Gunatillcke in 1985 showed that in five 5-ha plots, trees with a girth at breast height of more than $30 \mathrm{~cm}$ belonged to as many as 211 species. 119 genera, and 43 families. Some $66 \%$ of the species were endemic. About $86 \%$ of the individuals enumerated were of endemic species.

Another interesting area is the Knuckles Range, to the north-west of Kandy in the Central Highlands. Abeywickrama (1987) has shown that here. within a small arca of $150 \mathrm{~km}^{2}$. there is a sequence of vegetation types from dry mixed evergreen to wet evergreen montane forest, including patches of pygmy forest with small, muchbranched trees. seldom exceeding one metre in height. In the Knuckles. although the area is as yet incompletely botanized. more than a hundred fern and allied specics have been recorded, as against 314 for Sri Lanka as a whole and 600 for India.

Then again. recent studies in the Peak Wilderness montane forest have revealed formations dominated by several species of the endemic genus Stemonoporus of the family Dipterocarpaceae. including the rediscovered species, Is. rigidus. It has been remarked that perhaps no other dipterocarps in the world occur at higher elevations. The $S$ gardneri consociations at more than $1800 \mathrm{~m}$ in this forest are unique to Sri Lanka and should be conserved (Pahalawatte, 1993).

\section{The upper montane rain forests}

Hakgala Strict Nature Reserve, which belongs to the category of upper montane rain forest, extends upwards from $1500 \mathrm{~m}$. The forests are single-storeyed. Regrowth of young trees is sparse, under a dense canopy. The trees are stunted, about 3-4 $\mathrm{m} \mathrm{high}$, which is an adaptation to protect them against the strong winds. The crowns are umbrella-shaped with twisted branches. 
Punyalal,Ranasinghe

The most common genus in these forests is Callophyllum, represented by $C$ walkeri, $C$. trapezifolium and C. cuneifolium. In many areas the dominant Callophyllum walkeri trees surpass the general canopy by several metres, and attain stem sizes of $100 \mathrm{~cm}$ dbh. The associated families in these forests include the Myrtaceae, Lauraceae, and Theaceae. Species of Myrtaceae: Syzygium rotundifolium and S. sclerophyllum, are most abundant above 1800-2000 $\mathrm{m}$. Trees of the genera Cinnamomum, Litsea, Neolitsea, and Actinodaphne are also frequent. The family Theaceae is frequent up to $2200 \mathrm{~m}$. Above this height, the Lauraceae family is represented by Eurya japonica. Different species of Symplococus are evenly distributed in these forests. Rhododendron arboretum is the only tree seen on the adjacent wet "patana" grasslands. The shrub Strobilanthus is dominant in the undergrowth. Rhodomyrtus tomentosa is frequent on exposed peaks and forest fringes.

These upper montane rain forests reach their highest point in Piduruthalagala (2624 m). Species such as Syzvgium rotundifolium, S. sclerophyllum, Callophyllum walkeri, Osbeckia buxifolia, and Rhodo-myrtus tomentosa, that occur as trees inside the forests survive as shrubs on wind-exposed ridges. The vegetation on the slopes of wind channels will sometimes be lower than on the summit above. On the northern slope of Hakgala, bushes are sometimes as low as $20 \mathrm{~cm}$, but attain $100 \mathrm{~cm}$ on the summit itself. This low, compacted vegetation is shaped by the strong winds of the south-west monsoon and is therefore found on ridges rumning from north-west to south-east and on the slopes of gaps, where the monsoon winds are concentrated as in a funnel.

With increasing altitude there is a slight and gradual floristic change within the upper montane rain forests. Several species of the lower montane rain forests, such as Gordonia speciosa and Ternstroemia japonica are still present between 1500 and 1800 m. Even although these disappear above $1800 \mathrm{~m}$ others, such as Michelia nilagirica, Syzvgium rotundifolium, and Actinodaphne ambigua, are still found above $1800 \mathrm{~m}$. Several species such as Symplocos cordifolia, S. cochinchinensis, Garcinia echinocarpa, and Gordonia zeylanica disappear above $2000 \mathrm{~m}$. No new species appear above $2000-2100 \mathrm{~m}$, indicating that there is an impoverishment of the flora above this elevation; above $2400 \mathrm{~m}$ it consists mainly of Callophyllum walkeri, Syzygium rotundifolium, and Rhododendron arboreum. The dwarf bamboo Indocalamus debilis is replaced by I. wightianus above this height (Greller \& Balasubramaniam, 1980).

\section{Protection of biodiversity}

Closed-canopy forests cover nearly $24 \%$ of the island and open-canopy forests a further 7\% (Forest and Land Mapping Unit of the Forest Department, 1995). Most of this remaining forest is of the dry monsoon type, which is most extensive in the north and south-east of the island. Only fragments of tropical rain forest, few of them larger than 10,000 ha. remain in the wet zone of the south-west, where species diversity is highest. There are also plantation forests, mostly even-aged monocultures of teak, eucalypts, or pine, with some mixed ones of broadleaved species, such as jak and mahogany. Degraded natural forests have been enriched from time to time by line planting, often with mahogany (Forest Sector Master Plan of Sri Lanka, 1995). 
In proportion to its area, Sri Lanka has onc of the most cxtcnsive protected areas system of all tropical Asian countries, as it has about $7837 \mathrm{~km}^{2}$. or $11.9 \%$ of the land area. under protection. (UN. 1993, as quoted in the Forestry Sector Master Plan). Almost all the forests in the country are state-owned and come under the jurisdiction of either the Forest Department or the Department of Wildlife Conser-vation. Most of the forests under the Forest Department are designated as Forest Reserves or Proposed Forest Reserves. Those under the Deptartment of Wildlife Conservation are categorized into two broad types: National Reserves. and Sanctuaries. National Reserves are further classified into five types: Strict Natural Reserves. National Parks, Nature Reserves. Jungle Corridors, and Intermediate Zones (IUCN. 1993).

Many of the protected areas are small and isolated. reflecting the fragmented nature of much of the remaining natural habitat. About $30 \%$ of the individual protected arcas are less than 100 ha and $54 \%$ are less than 1000 ha. Whereas most of the protected areas under the Forest Department are smaller than 1000 ha. most of those under the Department of Wildlife Conservation are larger than 1000 ha. However, many of the Forest Department's small protected areas are "Man and the Biosphere Reserves". which are core areas of much larger forest or proposed reserves. Opportunities to protect large blocks of forests are becoming fewer (Forest Sector Master Plan of Sri Lanka. 1995).

Although considerable investments have been made in conserving biodiversity, existing data indicate that considerable losses have occurred from the reserves over the years. Only $66 \%$ of the total area ( 51,778 ha) of a selection of conservation forests is actually forested, and much of the other $34 \%$ has been converted from forest to other forms of land use. Comparisons of the original, notified boundaries of Hakgala, Horton Plains and Kanneliya with the present forest boundaries indicate that at least $12-18 \%$ of their total area has been lost to encroachment along the boundaries. The extent to which species are represented in the cxisting protected area system remains largely unquantified. In a review of the status of inventories for protected areas in the tropics, it was found that only 11 of the protected areas are known to have been inventoried for one or more plant or animal groups. Only one of the 21 inventories was judged to be comprehensive, namely that for plants in Ritigala Strict Natural Reserve (Forest Sector Master Plan, 1995). It is apparent. therefore, that a major obstacle to forest protection is the lack of biological information about the forests themselves.

The objective of the present investigation was to evaluate the conservation value of the Hakgala Strict Nature Reserve by assessing its floristic richness, diversity and endemism, rarity, naturalness and representativeness.

\section{Study site and methods}

\section{Study site}

Hakgala Strict Nature Reserve is occupied by upper montane rain forest. It lies $6 \mathrm{~km}$ south-east of Nuwara Eliya, in the Central and Uva Provinces. Its altitude ranges from 
about $1650 \mathrm{~m}$ to $2178 \mathrm{~m}$ at the top of Hakgala Peak. It contains three prominent peaks that are among the highest in the country. They are said to resemble the jaw of an elcphant, hence the Sinhalese name, from hak (jaw) gala (rock). The land was designated a Strict Nature Reserve in 1938, and placed under the jurisdiction of the Department of Wildlife Conservation. Its original forest area was 1141 ha, but in an inventory carried out in 1992 it was found that 181 ha or $15.9 \%$ of the total had been lost over the years by boundary encroachment. At present, it is under the IUCN management category $I$.

\section{Sampling}

The gradient directed transect (GRADSECT) sampling tcchnique was used, as it was reported to be able to capture more information than randomly placed transects of similar length (Gillison \& Brewer. 1985; Austin \& Heylingers, 1989). As altitude was considered the major environmental variablc affecting floristic diversity in this reserve, the transects were oriented up and down the slopes.

Plots of $5 \times 100 \mathrm{~m}$ were sampled along the transects at $150 \mathrm{~m}$ intervals. The first plot was placed about $100 \mathrm{~m}$ inside the periphery of the reserve to avoid disturbed areas. In these large plots a record was made of family, species, dbh, height and endemicity of woody perennials with a dbh of $10 \mathrm{~cm}$ or more. Smaller plots of $5 \times 5 \mathrm{~m}$ and $1 \times 1 \mathrm{~m}$ were randonly placed within the large plots, to sample the family, species, endemicity, number of individuals, and number of species, respectively of woody saplings with dbh less than $10 \mathrm{~cm}$ and height greater than $1 \mathrm{~m}$, and of seedlings with a height less than 1 m. Herbarium specimens were prepared for plants unidentified in the field, for later identification at the National Herbarium, Peradeniya.

\section{Position of transects}

Taking into consideration the amount of sunlight received in different parts of the reserve, it was divided into "sumny" and "less sunny" areas. Three transects were placed in sunny, and two in less sunny areas. Hakgala, Ambewela and Seetha Eliya fell into the first category while Martin Estate and Rendapola fell into the latter.

\section{Stand variables and ecological indices}

Relative density, relative frequency, and relative basal area were calculated by the formulas given below. The importance value index was calculated from these three parameters to characterize the species dominance of the reserve.

$$
\begin{array}{ll}
\text { Relative frequency }= & \begin{array}{l}
\text { total frequency of a species/total frequency of all } \\
\text { species }
\end{array} \\
\text { Relative density } & =\begin{array}{l}
\text { number of individuals of a species/total number } \\
\text { of individuals of all species }
\end{array}
\end{array}
$$




$$
\begin{array}{ll}
\text { Basal area } & =\pi \times(\mathrm{dbh})^{2} / 4 \\
\text { Relative basal area } & =\begin{array}{l}
\text { total basal area of a species/total basal area of all } \\
\text { species }
\end{array} \\
\text { Importance value index }=\begin{array}{l}
\text { relative density + relative basal area + relative } \\
\text { frequency }
\end{array}
\end{array}
$$

Ecological indices (diversity, evenness and dominance) were calculated for each piot by Shanon's diversity index as follows:

$$
\text { Diversity: } \quad \mathrm{H}^{\prime}=\mathrm{Pi} \times \log \mathrm{Pi}
$$

where $\mathrm{Pi}$ is proportional abundance

$$
\text { Evenness: } \quad \mathrm{J}^{\prime}=\mathrm{H}^{\prime} / \mathrm{H}^{\prime} \max
$$

where $\mathrm{H}^{\prime} \max =\log \mathrm{S}$, and $\mathrm{S}$ is the number of species found in the stand

$$
\text { Dominance }=1-J^{\prime}
$$

\section{Results and discussion}

\section{Floristic richness}

There were 69 tree species belonging to 52 genera and 32 families. Among the 182 saplings enumerated, there were 42 species belonging to 35 genera and 21 families. Among the 115 seedlings enumerated there were 28 genera and 19 families. In total

\begin{tabular}{|c|c|c|c|c|c|}
\hline Area & Plot No & $\begin{array}{l}\text { Alti- } \\
\text { tude } \\
\text { (m) }\end{array}$ & $\begin{array}{l}\text { Species in: } \\
\text { Canopy }\end{array}$ & Subcanopy & Understorey \\
\hline \multirow[t]{2}{*}{ Hakgala } & 1 & 1550 & $\begin{array}{l}\text { Semecarpus } \\
\text { coriacaea } \\
\text { Neolitsea cassia } \\
\text { Neolitsea fuscata } \\
\text { Syzygium } \\
\text { revolutum }\end{array}$ & $\begin{array}{l}\text { Acronychia } \\
\text { pedunculata } \\
\text { Allophylus } \\
\text { varians } \\
\text { Actinodapne } \\
\text { speciosa }\end{array}$ & $\begin{array}{l}\text { Psychotria zeylanica } \\
\text { Strobilanthus viscosa }\end{array}$ \\
\hline & 5 & 1600 & Meliosma & Acronychia & Psvchotria zevlanica \\
\hline
\end{tabular}
there were 88 species belonging 1065 genera and 36 families. The species found in the canopy, sub-canopy and understorey for each $5 \times 100-\mathrm{m}$ plot altitude are shown in Table 1, which also gives the altitude of each plot. The diversity, evenness, and dominance values are shown in Table 2. The least diversity was found on the top of the peak in the pigmy forest formation. Diversity and evenness were higher and dominance was lower at lower altitudes.

Table 1: Phytosociology 


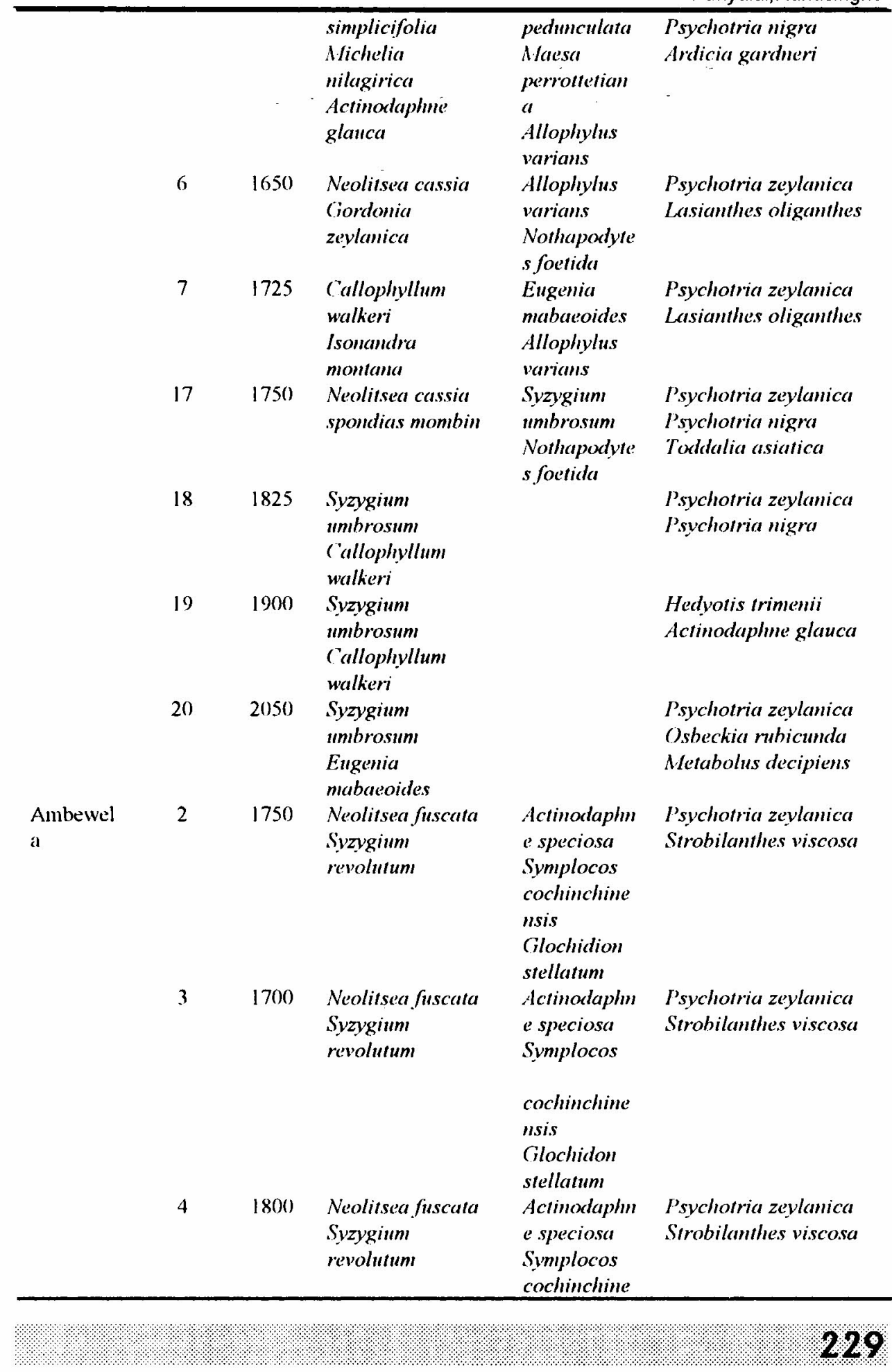




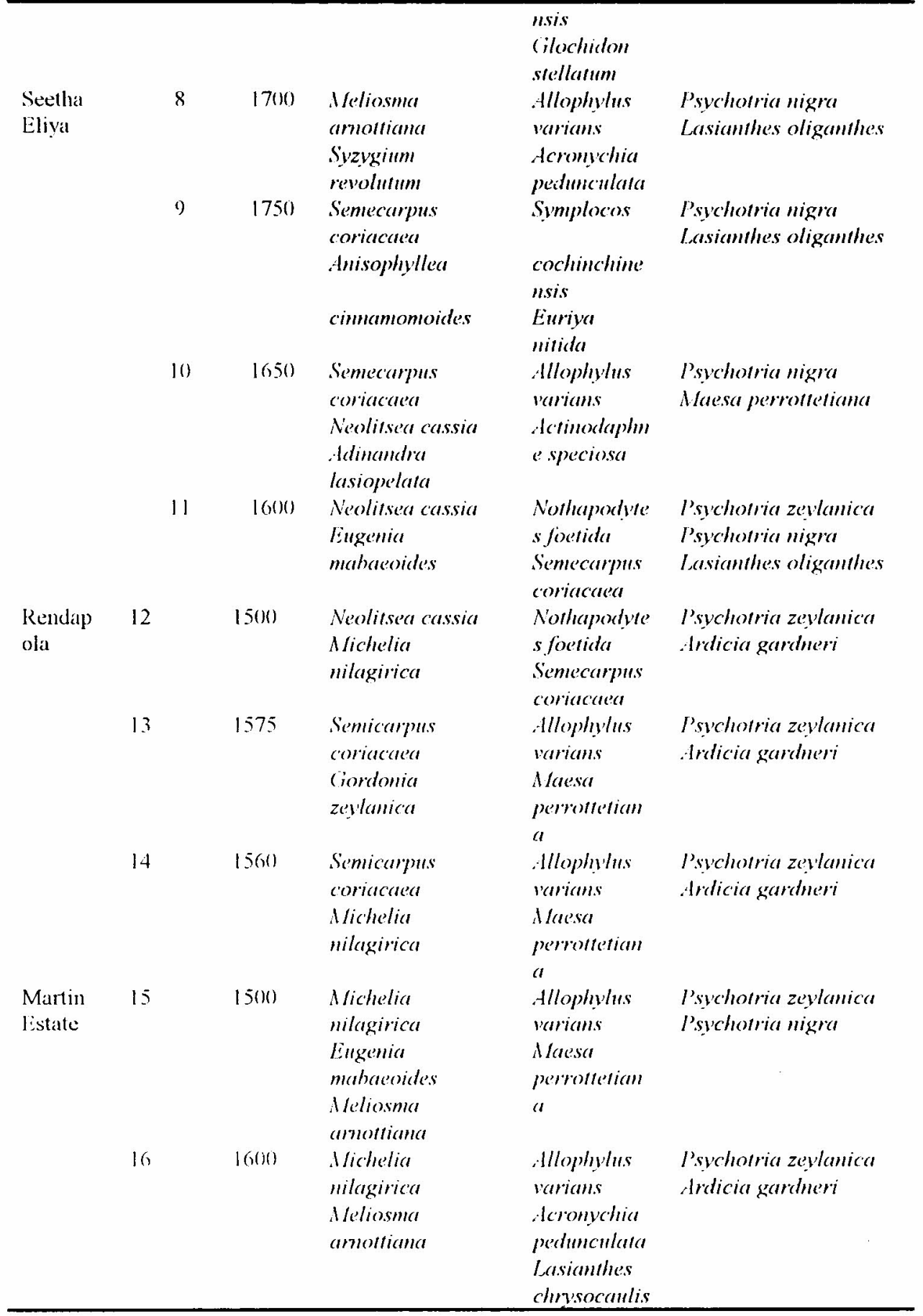


Table 2 : Diversity, evenness and dominance $(5 \times 100 \mathrm{~m}$ plots $)$

\begin{tabular}{clcccc}
\hline $\begin{array}{c}\text { Plot } \\
\text { No. }\end{array}$ & Area & $\begin{array}{c}\text { Altitude } \\
(\mathbf{m})\end{array}$ & Diversity & Evenness & Dominance \\
\hline 1 & Hakgala & 1550 & 1.04 & 0.57 & 0.43 \\
2 & Kande-Ela & 1750 & 0.80 & 0.44 & 0.56 \\
3 & -do- & 1700 & 0.65 & 0.35 & 0.65 \\
4 & -do- & 1800 & 0.50 & 0.27 & 0.73 \\
5 & Hakgala & 1600 & 1.08 & 0.59 & 0.41 \\
6 & -do- & 1650 & 1.26 & 0.68 & 0.31 \\
7 & -do- & 1725 & 1.18 & 0.64 & 0.36 \\
8 & Ambewcla & 1700 & 1.02 & 0.56 & 0.44 \\
9 & -do- & 1750 & 1.08 & 0.59 & 0.41 \\
10 & -do- & 1650 & 1.15 & 0.63 & 0.37 \\
11 & -do- & 1600 & 0.81 & 0.44 & 0.56 \\
12 & Rendapola & 1500 & 1.05 & 0.57 & 0.43 \\
13 & -do- & 1575 & 0.92 & 0.50 & 0.50 \\
14 & -do- & 1650 & 1.12 & 0.61 & 0.39 \\
15 & Martin & 1500 & 1.12 & 0.61 & 0.39 \\
& Eslatc & & & & 0.39 \\
16 & -do- & 1600 & 1.11 & 0.60 & 0.44 \\
17 & Hakgala & 1750 & 1.02 & 0.56 & 0.62 \\
18 & -do- & 1825 & 0.69 & 0.38 & 0.62 \\
19 & -do- & 1900 & 0.70 & 0.38 & 0.87 \\
20 & -do- & 2050 & 0.24 & 0.13 & \\
\hline
\end{tabular}

There was no single species dominance among the tree flora of the reserve. According to the importance value indices. four species: Psvchotria zeylanica. I'. nigra, Maesa perrottetiana, and Lasianthes oliganthes scemed to dominate the saplings. while $P$. zeylanica appcared to dominate the secdlings.

The importance value indices for the families represented among the trees. saplings, and secdlings are shown in Tables 3,4 and 5. According to the tables, the Rubiaccac was the most dominant family in both saplings and scedlings. The Lauraceae, Theaceac. Symplocaceae, Myrlaccae. Elcaocarpaceae, Cornaceae, and Rubiaceae were the most dominant among the trees. 
Annual Forestry Symposium, 1996

Table 3 : Importance Value Indices of tree families

\begin{tabular}{|c|c|c|}
\hline Family & IVI & \\
\hline Lauraceae & 0.178 & \\
\hline Theaceac & 0.151 & \\
\hline Symplocaceac & 0.149 & \\
\hline Myrtaceac & 0.143 & \\
\hline Eleaeocarpaceac & 0.134 & \\
\hline Cornaceae & 0.124 & \\
\hline Rubiaccae & 0.122 & \\
\hline Euphorbiaccac & 0.097 & - \\
\hline Ulmaceae & 0.088 & \\
\hline Allacardiaccae & 0.064 & \\
\hline Sabiaceac & 0.051 & \\
\hline Sapotaccae & 0.060 & \\
\hline Myrsinaceac & 0.046 & \\
\hline Rutaccac & 0.045 & \\
\hline Fabaceac & 0.044 & \\
\hline Melastomataceac & 0.036 & \\
\hline Verbenaceac & 0.027 & \\
\hline Tiliaceac & 0.026 & \\
\hline Magnoliaceac & 0.024 & \\
\hline Solanaccae & 0.024 & \\
\hline Staphyllaceac & 0.023 & \\
\hline Daphniphyllaceae & 0.023 & \\
\hline Sapindaceac & 0.021 & \\
\hline Cclastraccae & 0.020 & \\
\hline Rhizophoraceac & 0.019 & . \\
\hline Flacourtiaccac & 0.019 & \\
\hline Loganiaceac & 0.019 & \\
\hline Icanaceac & 0.016 & \\
\hline
\end{tabular}




\begin{tabular}{ll} 
Clusiaceae & 0.014 \\
Moraceae & 0.014 \\
Rhamnaceae & 0.014 \\
Melastomataceae & 0.025 \\
Clusiaceae & 0.017 \\
Euphorbiaceae & 0.012 \\
Anacardiaceae & 0.012 \\
Ericaceae & 0.012 \\
Rhizophoraceae & 0.008 \\
Lamiaceae & 0.008 \\
Sabiaceae & 0.004 \\
Buxaceae & 0.004 \\
\hline
\end{tabular}

There were no major community types in the reserve except at the summit, at altitudes above $1825 \mathrm{~m}$. where the pigmy forest formation was observed. Here there were scattered trees of Callophyllum walkeri, Syzygium umbrosum and Eugenia mabaeoides which formed a community above the understorey. There were only two strata, canopy and understorey, at the summit (see Table 1). These findings are comparable to those reported in IUCN, 1993 on montane forests in Sri Lanka. However, Wijesundara (1991) reponed the dominance of Syzvgium sclerophyllum, S. revolutum, and Osbeckia buxifolia around the peak of the Hakgala Reserve. He also reported the presence, at lower elevations. of four minor woody-plant communities: Psychotria bisulataAllopylus varians-Michelia nilagirica, the Actephila neilgherrebsis-Pettosporum tetraspermum-Alarena subcoriacea, the Syzvgium revolutum-Psychotria spp.Neolitsea fuscata, and the Ilex walkeri-Symplocos suborbicularis-Syzygium rotundifolium. Although these communities were not identified in the present study a canopy-level community of (allophyllum walkeri-Syzygium umbrosum-Eugenia mabaeoides was identified at the peak.

Table 4: Importance Value Indices of sapling families

\begin{tabular}{lc}
\hline \multicolumn{1}{c}{ Family } & IVI \\
\hline Rubiaceae & 1.015 \\
Myrsinaccac & 0.435 \\
Myrtaceac & 0.120 \\
Symplocaceae & 0.098 \\
Lauraceae & 0.092 \\
Buxaceae & 0.054 \\
Sapindaceae & 0.054 \\
Rutaceae & 0.032 \\
\hline
\end{tabular}




\begin{tabular}{ll}
\hline Anacardiaceae & 0.032 \\
Sabiaceae & 0.014 \\
Melastomataceae & 0.012 \\
Piperaceae & 0.008 \\
Lacinaceac & 0.006 \\
Clusiaceae & 0.006 \\
Loganiaceae & 0.004 \\
Rhamnaceae & 0.004 \\
Daphiniphyllaceae & 0.002 \\
Celastraceac & 0.002 \\
Euphorbiaceac & 0.002 \\
Verbenaceae & 0.002 \\
Theaceae & 0.002 \\
\hline
\end{tabular}

Endemism in this reserve is about $44 \%$ of the species enumerated. Two plant species, Syzygium spathulatum and Gordonia zeylanica, that are found in the reserve have been listed as endangered. In addition, the reserve contains two species classified as vulnerable, seven as rare. and four species as intermediatc (World Conservation and Monitoring Centre, 1995). Wijesundara (1991) reported 50\% cndemism of the total enumerated flora in a sampling area of 1.25 ha in the reserve. The high endemism encountered in this montane forest reserve is supported by the findings of many researchers (Peeris, 1975; Gunatilleke and Gunatilleke, 1983; Gunatilleke and Ashton, 1987; and IUCN, 1993).

Table 5 : Importance Value Indices of seedling families

\begin{tabular}{|c|c|}
\hline Family & IVI \\
\hline Rubiaceace & 1.129 \\
\hline Myrsinaceae & 0.225 \\
\hline Symplocaceae & 0.121 \\
\hline Lauraceae & 0.117 \\
\hline Acantliaceae & 0.062 \\
\hline Rhamnaceae & 0.058 \\
\hline Loganiaceae & 0.046 \\
\hline Theaceae & 0.042 \\
\hline Rutaceae & 0.042 \\
\hline Myrtaceae & 0.038 \\
\hline
\end{tabular}

Distribution of tree diameters 
The diameter distribution of the trees enumerated shows a reversed J-shaped distribution. About $65 \%$ of the trees had a dbh of $20 \mathrm{~cm}$ or more. Species like Semecarpus coriacaea and Mfichelia nilagirica had the greatest $\mathrm{dbh}$. with the values excceding $100 \mathrm{~cm}$.

\section{Viability of the reserve}

Apant from its floristic richness and categorization as an ecologically critical area, the reserve acts as a valuable watershed. fecding many perennial streams. Some of them contribute to the Uma Oya, which is a major tributary of the Mahaweli River, the largest river in the country and the source of the main irrigation scheme of the country. However, because of its small size and isolated location. its long term viability could be threatened. Some of the threats are human interference. particularly felling trees for firewood: dic-back of trees: and invasion of natural vegetation by exotic species escaped from the Hakgala Royal Botanic Garden at the foot of the reserve. At present there are three exolic species, (estrum aurantiacum, Eupatorium riparium, and Aristea ecklonii, which are believed to compete with the natural vegetation (Wijesundara, 1991). In the preparation of a conservation management plan for the reserve, it is essential to take all these factors into consideration if long-term sustainability is to be preserved.

\section{References}

Abeywickrama, B.A. (1987). The threatened plants of Sri Lanka. Natural Resources, Energy and Science Authority of Sri Lanka.

Austin. M.P. and Heylingers, M.P. (1991). New approaches to vegetation survey design - grandsect sampling. In: Nature conservation, cost effective biological surveys and data analysis (Eds. C.R. Margules and M.P. Austin). Australia, CSIRO.

Gillison, A.N. and Brewer, K.R.W. (1985). The use of gradient directed trasects or gradsects in natural resources surveys. Journal of Environment Management. 20 .

Greller. A.M. and Balasubramanium. S. (1980). A preliminary floristic-climatic classification of forests of Sri Lanka. Sri Lanka Forester 14 (3/4).

Gunatillekc. C.V.S. and Ashton. P.S. (1987). New light on the plant geography of Ceylon, II The ecological biography of the lowland endemic flora. Journal of Biogeography 14, 295-327.

Gunatilleke. C.V.S. and Gunatilleke, I.A.U.N. (1985). Phytosociology of Sinharaja - a contribution to rain forest conservation in Sri Lanka. Biological Conservation 31. $21-40$. 
Gunatilleke, I.A.U.N. and Gunatilleke. C.V.S. (1983). Conservation of natural forests in Sri Lanka. Sri Lanka Forester 16 (1/2) 39-54.

IUCN (1993). Biological conservation in Sri Lanka - a national status report. Colombo, IUCN Sri Lanka Country Office.

Pahalawatte, K.K. (1993). Phytosociological analysis of Adam's Peak Wilderness Sanctuary. M.Sc. thesis, Forestry Unit, University of Sri Jayewardenepura.

Peeris, C.V.S. (1975). The ecologv of endemic tree species of Sri Lanka in relation to their conservation. Ph.D. thesis, University of Aberdeen.

Wijesundara, D.S.A. (1991). Phytosociology of a montane forest in Sri Lanka. M.Phil. thesis, Faculty of Science, University of Peradeniya.

World Conservation and Monitoring Centre (1995). Sri Lanka nationally threatened taxa conservation status listing of plants. 